\title{
현장형 공적개발원조(ODA) 사업의 성과: 아제르바이잔 KOICA-IOM 카흐리즈 수자원시스템 복원사업 사례를 중심으로
}

김 영 우 (KOICA 기획예산실 과장)

\section{목 차}

1. 안나 까레니나의 법칙

2. 아제르바이잔 ODA 수원현황 및 물분야 개발과제

3. 카흐리즈(Kahriz) 수자원시스템 복원사업

4. 한국 ODA에 대한 시사점

\section{1. 안나 까레니나의 법칙}

“Все счастливые семьи похожи друг на друга, каждая несчастливая семья несчастлива по-своему”

세계적으로 유명한 위 문구는 러시아의 대문호 톨스토이가 1877년에 발표한 소설 '안나 까레 니나(Anna Karenina)' 의 첫 문장이다. 이 문장의 뜻은 영어로는 “All happy families are alike; each unhappy family is unhappy in its own way", 한국어로 의역해 보면 “행복한 가정은 모두 비슷한 이유들로 인해 행복하고, 불행한 가정은 각기 다른 이유들로 인해 불행하 다”로 볼 수 있다.

이 문구에 영감을 얻은 '총·균·쇠(GUNS, GERMS, and STEEL)' 의 저자 제레드 다이아 몬드는 퓰리처상을 수상한 자신의 책에서 각 대륙의 환경이 인류의 발전에 미치는 역학관계를 분석하며, 동식물 종의 수에 대해 이른바 '안나 까레니나의 법칙' 을 적용하며, 다음과 같이 설 
명한다. "가축화 할 수 있는 동물은 모두 엇비슷하고, 가축화할 수 없는 동물은 가축화할 수 없 는 이유가 제각기 다르다". 이는, '가축화 할 수 있는 동물은 가축화 할 수 있는 이유가 대부분 비슷하지만, 가축화 할 수 없는 동물은 어떠한 이유로 인해 가축화 될 수 없는데, 그 이유는 제 각기 다르다' 라는 의미로 해석할 수 있다.

여기서, 우리는 개발 분야에서도 소위 '행복한 선진국(행복한 가정)' 과 '불행한 개발도상국 (불행한 가정)'을 이해하는 데에 있어서 '안나 까레니나의 법칙'으로부터 영감을 얻을 수 있다. '선진국을 선진국답게 하고 선진국일 수밖에 없게 하는 이유는 몇 가지로 쉽게 요약될 수 있는 데 비해, 세계의 수많은 개발도상국가가 개발도상국가인 이유는 그 개발도상국가 숫자만큼이나 다양한 듯이 보인다' 물론, 개발도상국가의 문제점들을 대표적인 몇 가지로 분류할 수도 있겠 지만, 그것보다 '안나 카레니나의 법칙 '이 우리에게 주는 통찰은 그 개발도상국들이 선진국을 선진국 되게 하는 몇 가지 이유들을 갖춘다고 해서 다른 문제들을 덮고 선진국이 될 수 없다는 점에 있다.

이를 다시 설명하자면, 개발도상국이 선진국이 되고자 한다면 선진국을 선진국이게 하는 요인 (행복한 이유)을 찾기 보다는 우선 개발도상국에 머무르게 하는 이유(불행한 이유)를 먼저 찾아 해결하는 것이 순서일 것이라는 뜻이다. 물론, 모두가 알고 있듯이 '안나 까레니나의 법칙' 이 다른 법칙들과 같이 증명할 수 있는 진정한 의미의 법칙은 아니다. 그러나, 그 의미를 음미하면 서 개발협력사업이 그리고 우리나라의 $\mathrm{ODA}$ 사업이 어떠한 방향성을 가져야 할지에 대해서는 한번 쯤 깊이 생각해 볼 필요가 있다.

이와 관련, 개발도상국의 발전을 위해 추진되는 개별사업들도 선진국에 적용가능한 기술이나 요소들을 지향하며 사업이 설계되고 추진될 것이 아니라, 각 개발도상국가의 상황과 문제에 따 라 그 내용이 달라져야 할 것이다. 비록, 어떠한 사업이 단 한 지역에서만 또는 아주 제한된 범 위에서만 그 효용성을 가진다 할지라도, 그로인해 개발도상국이 가진 수많은 문제들 중 하나를 확실히 해결 할 수 있다면 엉성하게 마스터키를 자처하는 사업보다 그 효과나 가치는 크다고 할 수 있다. 따라서, 본고에서는 이처럼 수원국 현지 특성에 맞게 사업이 발굴되고 추진된 사례를 아제르바이잔의 물분야 사업인 '카흐리즈 수자원시스템 복원사업' 을 통해 살펴보고, 한국 $\mathrm{ODA}$ 전반에 주는 시사점을 찾아보고자 한다. 


\section{2. 아제르바이잔 ODA 수원현황 및 물분야 개발과제}

\section{1) 아제르바이잔 개요}

구소련 국가 중 아직은 우리에게 생소한 국가인 아제르바이잔(Azerbaijan)은 유라시아 지역 남코카서스(South Caucasus) 산맥 아래에 위치한 국가(인구 약 900만명)로서, 카스피해(동 쪽), 터키(서쪽), 러시아(북쪽), 이란(남쪽)과 국경을 접하고 있다.

아제르바이잔은 페르시아어 ‘아자르(Adhar:불)' 와 아랍어 ‘바이잔(Beyqan : 나라)' 에서 유래한 것으로 '불의 나라' 라는 의미를 가지고 있는데, 고대부터 천연가스가 많아 지표면으로 부터 가스가 분출되어 불이 솟구쳐 올라왔으며 이로 인해 불을 숭상하는 조로아스터교(배화교) 가 성행하기도 하였다.

또한, 아제르바이잔은 가스뿐만 아니라 석유 매장량도 풍부한 곳으로 카스피해 연안지역인 수 도 바쿠에서는 1848년 세계 최초로 원유 상업채굴을 시작하였고, 1930년 바쿠의 원유생산은 거의 1 억 배럴에 달했는데 이는 그 당시 세계 3 위 수준이었다. 19 세기 말부터 20 세기 초에 석유 개발과 주변지역으로의 수송이 본격화되면서 유럽 러시아 、 터키 - 미국 등 세계열강들의 관심 을 받으며 크게 성장하였으나, 이들의 이해관계와 민족 간 대립 속에서 결국 1920 년에 소비에 트 연방에 병합됐다.

소련이 붕괴한 이후 아제르바이잔은 1994년 석유개발 재개를 위한 서구 메이저 기업들과 맺 은 '세기의 계약(Contract of Century)' 을 통해 독립 후 여타 CIS 국가에 비해 상대적으로 순 조로운 출발을 할 수 있었다. 2000년대 후반에는 유가 상승에 힘입어 연 $20 \%$ 이상의 GDP 성 장률을 보였고, 급격한 경제성장을 이룩해가는 과정에서 빈곤문제도 점차 해결해 나가고 있다.

\section{2) 아제르바이잔 ODA 수원 현황}

아제르바이잔은 석유 및 가스개발로 벌어들이는 수입으로 인해, 천연자원이 부족한 주변국인 조지아(Georgia)와 아르메니아(Armenia)에 비해 국내총수입(GNI) 중 ODA가 차지하는 비중 이 2010년 기준 0.3\%로 상당히 적은편이다. 1인당 국민소득 또한 USD 5,080(2010년 기준) 수 준으로 $\mathrm{OECD} \mathrm{DAC(경제개발협력기구} \mathrm{개발원조위원회)} \mathrm{수원국} \mathrm{리스트에서도} \mathrm{고중소득국으로}$ 분류된다. 즉, 국가경제를 운영해 나가는데 있어 ODA가 기여하는 부분이 다른 개발도상국가 비교하여 상대적으로 적다는 뜻이다. 


\section{〈아제르바이잔 ODA 수원현황(2008-2010) 요약 〉}

\section{Azerbaijan}

\begin{tabular}{|lrrr|}
\hline Receipts & 2008 & 2009 & 2010 \\
\hline Net ODA (USD million) & 235 & 232 & 156 \\
Bilateral share (gross ODA) & $64 \%$ & $65 \%$ & $52 \%$ \\
Net ODA / GNI & $0.6 \%$ & $0.6 \%$ & $0.3 \%$ \\
& & & \\
Net Private flows (USD million) & 2390 & 614 & 338 \\
\hline & & & \\
\hline For reference & 2008 & 2009 & 2010 \\
\hline Population (million) & 8.8 & 8.9 & 9.0 \\
GNI per capita (Atlas USD) & 3790 & 4750 & 5080 \\
\hline
\end{tabular}

\begin{tabular}{|ll|}
\hline $\begin{array}{c}\text { Top Ten Donors of gross } \\
\text { ODA (2009-10 average) }\end{array}$ & [USD m] \\
\hline 1 IDA & 45 \\
2 Germany & 38 \\
3 United States & 38 \\
4 Turkey & 25 \\
5 EU Institutions & 17 \\
6 France & 17 \\
7 AsDB Special Funds & 10 \\
8 Global Fund & 8 \\
9 lsl.Dev Bank & 6 \\
10 Japan & 6 \\
\hline
\end{tabular}

Bilateral ODA by Sector (2009-10)

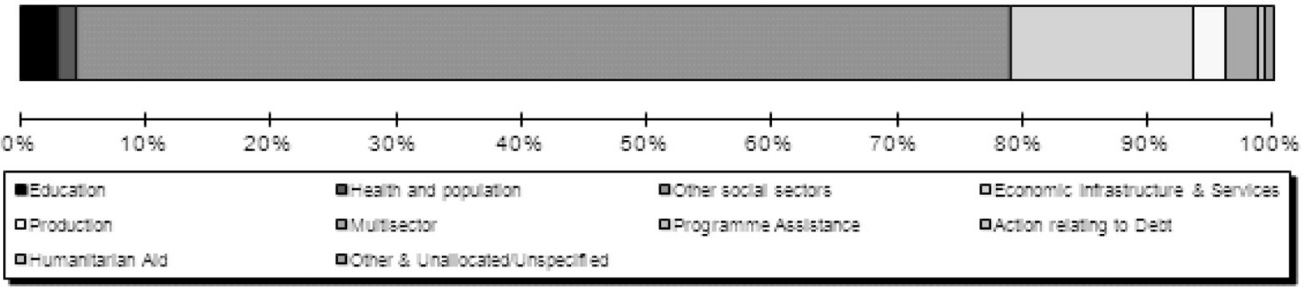

Sources: OECD, World Bank.

그러나, 지난 20 년간 급격히 개선된 경제·사회지표에도 불구하고, 아제르바이잔은 진정한 의미의 발전을 위해 여느 개도국과 마찬가지로 다양한 분야에서 양적, 질적 개선을 필요로 한 다. 이를 위해, 아제르바이잔 정부는 '2008-2015년 빈곤감소와 지속가능한 발전을 위한 국가 계획(SPPRSD : State Program on Poverty Reduction and Sustainable Development)' 과 같은 국가개발전략을 수립하고, 구체적인 개발목표( 9 개 전략목표/ 34 개 세부 추진목표)를 달 성하기 위해 정부 자체적으로 사업을 추진하거나, 국제기구(세계은행, $\mathrm{ADB}, \mathrm{UNDP}$ 등) 및 각 공여국(미국, 독일, 프랑스, 일본, 한국 등)으로부터 ODA를 지원받고 있다.

이와 관련하여 세계적인 물부족 국가인 아제르바이잔은 안정적인 수자원 확보 및 각 지방의 원활한 상수공급 및 하수처리를 위해 동 분야를 $\operatorname{SPPRSD}(2008-2015)$ 의 주요 개발목표로 삼 아 국제사회와 함께 다양한 협력사업을 추진하고 있다. 


\section{3) 아제르바이잔 물분야 개발과제}

아제르바이잔은 지표수 중 주요 하천(Kur강, Araz강, Samur강)을 포함한 대부분의 하천(약 70\%)이 타국으로부터 발원되어 안정적인 수자원 확보가 어렵다. 더욱이, 전반적으로 강우량도 적은 아제르바이잔의 연간 수자원량은 $\mathrm{km}^{2}$ 당 약 $100,000 \mathrm{~m}^{3}$ (연간 1 인당 수자원량 $1,200 \mathrm{~m}^{3}$ )이며, 이는 남코카서스 지역 주변국인 조지아와 비교하여 약 8.3배 적은 규모이다.1)

이에, 물문제는 인간의 기본욕구(Basic Human Needs)를 충족시키기 위한 필수 요소로서 $\operatorname{SPPRSD}(2008-2015)$ 내에서 그 중요성이 강조되고 있으며, 아제르바이잔 정부가 2010년을 '물의 해’ 로 지정할 만큼 전 국가적으로 물 문제를 중요한 개발과제로 인식하고 있다.

\section{〈SPPRSD(2008-2015) 9대 34개 목표중 물분야 관련 전략목표 〉}

\begin{tabular}{l|l|l}
\hline \multicolumn{1}{c|}{ 관련 전략 목표 } & \multicolumn{1}{|c}{ 세부 추진 목표 } & \multicolumn{1}{|c}{ 평가 지표 및 기준 } \\
\hline $\begin{array}{l}\text { 사회 제반 시설 개발과 } \\
\text { 공공 시스템 향상 }\end{array}$ & $\begin{array}{l}\text { '15년까지 지역단위 샘물과 지하수원 사앵 } \\
\text { 현하고, 죽앙 망물 공급 체계를 통해 전 인구 } \\
\text { 에게 물 공급 }\end{array}$ & $\begin{array}{l}\text { 지역단위 마을에서 } \\
\text { 안정적으로 물을 } \\
\text { 공급받는 인구비율: } \\
46.5 \% \text { ('07) }\end{array}$ \\
\hline $\begin{array}{l}\text { 환경 상황 개선과 } \\
\text { 지속 가능한 환경 관리 }\end{array}$ & $\begin{array}{l}\text { '15년까지 전국 하수 처리 100\% 달성 } \\
\text { 대도시 하수처리비 } \\
\text { 율: } 57.9 \% \text { ('06) }\end{array}$ \\
\hline
\end{tabular}

출처: 아제르바이잔 SPPRSD 2008-2015

또한, 아제르바이잔 정부는 $\operatorname{SPPRSD}(2008-2015)$ 의 물분야 개발목표를 성공적으로 달성하 기 위하여, 보다 구체적으로 '2009-2013년 지역별 사회경제개발전략(SPSEDR : State Programme on Socio-Economic Development of the Regions)'을 통해 아제르바이잔 전 체를 10 개의 경제구역*으로 나누고, 지역별 세부추진 계획에 따라 물분야 사업들을 추진하고 있다.

* 10개 경제구역 : Baku, Absheron, Aran, Upper Shirvan, Ganja-Gazakh, GubaKhachmaz, Lenkeran, Naxchivan, Sheki-Zagatala, Upper Garabagh

1) Source: National Hydrometeorological Department, Ministry of Ecology and Natural Resources of Azerbaijan Republic, http://www.azhydromet.com 
〈SPSEDR(2009-2013) 수자원개발 관련 세부 추진 계획 (Baku 지역) 〉

\begin{tabular}{l|l|c}
\hline 경제구역별 & \multicolumn{1}{|c}{ 주요 추진 내용 } & \multicolumn{1}{c}{ 기간 } \\
\hline \multirow{5}{*}{ Baku } & • 노후 파이프라인 교체 & $2010-2013$ \\
\cline { 2 - 3 } & • 주거지역내 수도배관 교체 & $2009-2013$ \\
\cline { 2 - 3 } & • 주거지역 물 공급 시스템 개선 & $2009-2012$ \\
\cline { 2 - 3 } & • 주거지역 위생 시설 개선 & $2009-2012$ \\
\cline { 2 - 3 } & • 하수처리시설 확대 & $2010-2013$ \\
\cline { 2 - 3 } & • 물 공급 개선을 위한 급수장 재건 및 신축 & $2009-2012$ \\
\hline
\end{tabular}

출처: 아제르바이잔 SPSEDR 2009-2013

\section{4) 아제르바이잔 물분야 ODA 사업}

아제르바이잔의 물문제 해결을 위해 세계은행과 같은 국제금융기구와 DAC 공여국의 원조기 관들은 주로 상하수도 시설 개선을 위하여 대규모 재원을 지원하고 있으며, 우리나라의 수자원 공사 및 농어촌공사와 같이 아제르바이잔 내 수자원관련 기반시설을 건설하고 운영하는 'AZERSU' 와 ‘Water Amelioration' 이 다음과 같은 재원을 통해 사업을 추진하고 있다.

\section{〈아제르바이잔 물분야 ODA (상하수도시설 건설지원) 사업 현황 〉}

\begin{tabular}{|c|c|c|c|c|c|}
\hline 공여기관 & 수원기관 & 사업대상지역 & 지원형태 & 추진현황 & 지원금액 \\
\hline ADB & Azersu & $\begin{array}{l}\text { Goychay, Agdash, } \\
\text { Beylagan Nakchivan }\end{array}$ & 차관 & 진행중 & 4억5백만불 \\
\hline $\begin{array}{l}\text { Islamic } \\
\text { Development } \\
\text { Bank }\end{array}$ & Azersu & $\begin{array}{l}\text { Gazakh, Samukh, Terter, } \\
\text { Dashkesan, Gedebey, } \\
\text { Astara }\end{array}$ & 차관 & 진행중 & 4억5백만불 \\
\hline JICA(일본) & Azersu & $\begin{array}{l}\text { Shilvan, Khizi, Barda, } \\
\text { Salyan, Yevklah, Guzar, } \\
\text { Gobustan, Khadimaz, } \\
\text { Neftchala, Naftalan }\end{array}$ & 차관 & 진행중 & 329억엔 \\
\hline \multirow{2}{*}{$\begin{array}{l}\mathrm{KfW} \text { (독일) } \\
\mathrm{SECO} \text { (스위스) }\end{array}$} & \multirow{2}{*}{ Azersu } & \multirow{2}{*}{ Ganja, Sekhi } & $\begin{array}{l}\mathrm{KfW} \\
\text { 차관 }\end{array}$ & 진행중 & 3,700만 유로 \\
\hline & & & $\begin{array}{l}\text { SECO } \\
\text { 무상원조 }\end{array}$ & 진행중 & 1,000만 유로 \\
\hline
\end{tabular}




\begin{tabular}{|c|c|c|c|c|c|}
\hline 공여기관 & 수원기관 & 사업대상지역 & 지원형태 & 추진현황 & 지원금액 \\
\hline \multirow{3}{*}{$\begin{array}{l}\mathrm{KOICA} \\
\text { (한국) }\end{array}$} & $\begin{array}{l}\text { Water } \\
\text { Ameliorati } \\
\text { on }\end{array}$ & $\begin{array}{l}\text { 아제르바이잔 북부하천취수시설 } \\
\text { 및 압세론수로개보수를 위한 타 } \\
\text { 당성조사 및 실시설계 지원 }\end{array}$ & 무상원조 & $\begin{array}{l}\text { 2011년 } \\
\text { 종료 }\end{array}$ & 340만불 \\
\hline & Azersu & Kurdakhani & 무상원조 & 진행중 & 2,600만불 \\
\hline & 지방정부 & Naftalan, Barda 등 8개 지역 & 무상원조 & 진행중 & 120만불 \\
\hline $\begin{array}{l}\text { 한국수출입 } \\
\text { 은행 }\end{array}$ & Azersu & Pirshagi & 차관 & 추진예정 & 4,350만불 \\
\hline \multirow{4}{*}{ World Bank } & Azersu & Guba, Shamkhi 등 21개 지역 & IBRD 차관 & 진행중 & 2억3천만불 \\
\hline & \multirow{2}{*}{$\begin{array}{l}\text { Water } \\
\text { Ameliora } \\
\text { tion }\end{array}$} & \multirow{2}{*}{$\begin{array}{l}\text { Lankaran, Kurdamir 등 } \\
21 \text { 개 지역 }\end{array}$} & $\begin{array}{l}\mathrm{IBRD} \\
\text { 차관 }\end{array}$ & 진행중 & 2억3천만불 \\
\hline & & & $\begin{array}{l}\text { IDA } \\
\text { 차관 }\end{array}$ & 진행중 & 3,000만불 \\
\hline & $\begin{array}{l}\text { Ministry } \\
\text { of } \\
\text { Education }\end{array}$ & NR & $\begin{array}{l}\text { IDA } \\
\text { 차관 }\end{array}$ & 진행중 & 800만불 \\
\hline
\end{tabular}

출처 : 아제르바이잔 물분야 공여국회의 자료(2011.9.14.)

우리나라도 아제르바이잔 물분야 ODA 사업에서 일본, 독일 등과 함께 주요 공여국 가운데 하나로서, 특히 동아시아기후파트너십(EACP : East Asia Climate Partnership) 물랜드마크 사업 지원을 통해 아제르바이잔 내 물분야 무상원조 규모로는 가장 큰 규모(약 2,600만불)의 사 업을 추진 중에 있다. 또한, 보다 규모있는 사업을 실현하고 효과성 제고를 위해 한국수출입 은행은 $\mathrm{EDCF}$ (Economic Development Cooperation Fund) 자금(약 4,350만불)도 지원할 예정이다. 무상원조 자금으로는 압세론반도 내 쿠르다카니(Kurdakhani) 지역에 상하수도 관 망을 구축하고, 유상원조 자금으로는 피르샤기(Pirshagi) 지역에 하수처리장을 건설하여 동 지 역의 상수공급 및 하수처리 개선에 기여할 것으로 기대된다.

그 밖에도, 우리나라 정부는 2009-11년간 약 340만불의 무상원조 자금으로 KOICA를 통해 아제르바이잔 동북부 지역 6 개 하천의 취수시설 건설과 압세론반도 내 수로개보수 사업을 위한 타당성조사 및 실시설계 수립을 지원하였으며, 2010년 7월부터 2012년 12월까지 120만불의 자 금으로 국제이주기구(IOM : International Organization for Migration)와 함께 아제르바이 잔 서북부 산간지역의 훼손된 카흐리즈 수자원시스템 20개를 복원하는 사업을 추진하고 있다.

우리나라가 아제르바이잔에 지원하는 물분야의 다양한 ODA 사업 중 본고에서는 특히 120 만 불로 사업예산은 가장 적지만, 현지 특성에 맞게 사업이 발굴되고 추진되어, 적은 비용 대비 큰 효과를 나타내는 것으로 평가되는 ' $\mathrm{KOICA}-\mathrm{IOM}$ 카흐리즈 수자원시스템 복원사업' 의 사례를 
구체적으로 살펴보고자 한다. 이 사업은 아제르바이잔의 ODA 모범사례2) 중 하나로 손꼽히기 도 하며, 일부러 큰 재원과 현대화된 기술을 도입하지 않더라도, 수원국 상황에 대한 철저한 이 해를 바탕으로 지속가능한 사업을 설계한다면, 분명 규모는 작지만 효과는 큰 사업을 만들 수 있다는 것을 보여주는 좋은 사례이다.

\section{3. 카흐리즈(Kahriz) 수자원시스템 복원사업}

\section{1) 카흐리즈 복원사업의 추진배경}

카흐리즈 수자원시스템은 전통적으로 아제르바이잔 서부 산간지역에서 지하수를 이용하기 위 한 시스템으로서 이란, 아랍, 북아프리카, 중국(과거 한국, 일본 일부지역 포함) 및 실크로드 지 역, 남미 일부지역에 이르기까지 강수량이 적은 건조지역에 널리 퍼져 있던 독특한 수자원관리 시스템3) 중 하나이다. 카흐리즈는 지대 간의 경사차를 이용, 지하수로를 통해 흐르는 지하수를 식수 및 생활 · 농업용수로 이용 가능하게 하는 시스템이나, 아제르바이잔의 카흐리즈는 소련시 절 동안 정부와 주민들의 무관심으로 대부분의 시설물이 방치 · 훼손 되었다.

\section{〈아제르바이잔 카흐리즈 분포도 〉}

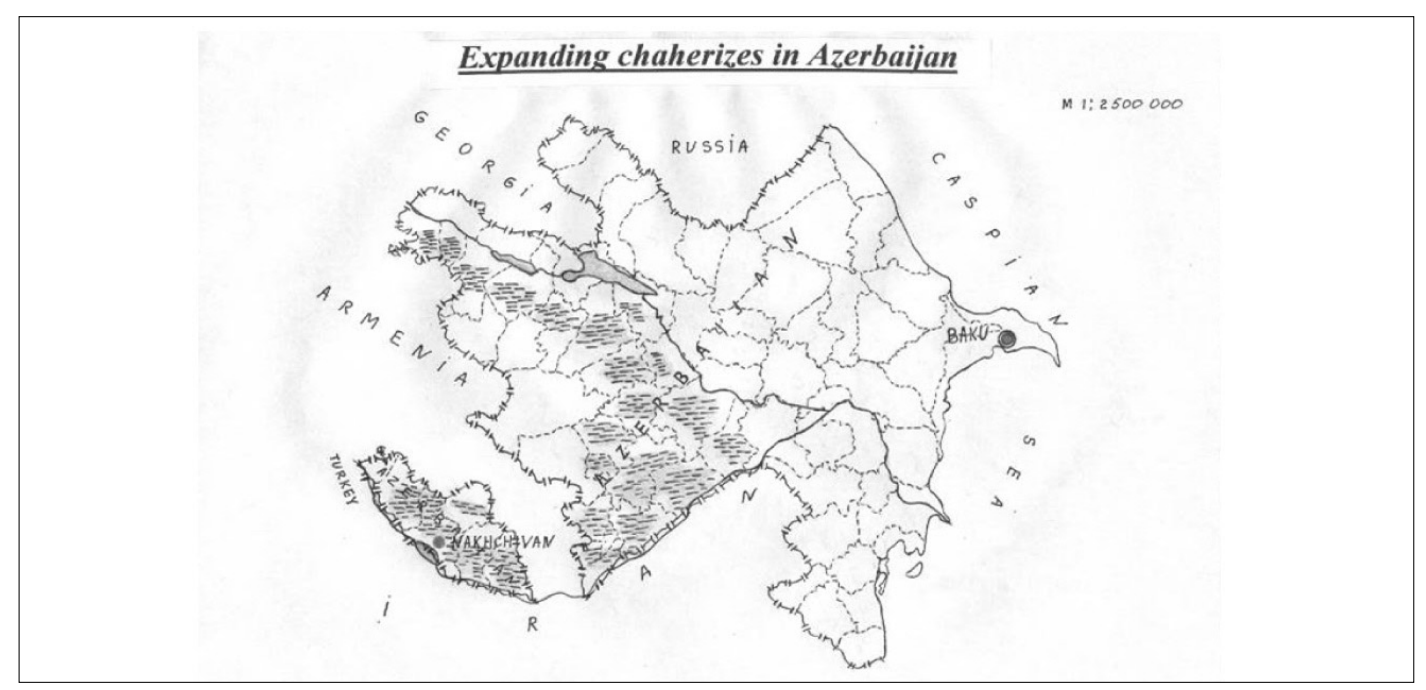

2) 카흐리즈 수자원시스템 복원사업은 2012년 Energy Globe Award의 아제르바이잔 national winner로 선정 됨.(www.energyglobe.info)

3) 동 시스템은 각 국마다 다른 이름으로 불렸으며, 아제르바이잔에서는 Kahriz, 이란에서는 Qanat, 일본에서는 Manbo 라는 이름으로 불렸다. 
이로 인해, 아제르바이잔 서부 산간지방에는 물공급이 제대로 이뤄지지 못했고, 물부족으로 인한 주민들의 이주 문제를 해결하기 위해 IOM은 1998년부터 동 시스템 복원사업을 시작하였 다. 사업 초반에는 각 지방정부 관계자 및 주민들은 카흐리즈를 복원하여 물을 공급할 수 있다 는 것에 대해 의구심을 품고, 일반적으로 통용되는 우물을 파거나 또는 대대적으로 상수공급을 위한 현대화된 시설물을 구축해야만 문제를 해결할 수 있다고 생각하였다. 그러나, 카흐리즈가 하나둘씩 복원되면서 그 효과가 나타나기 시작하였고, 대규모 재원 투입 없이 복원이 가능하고, 복원 후에도 유지관리에 대한 비용 부담도 크지 않아 사업의 효과성(effectiveness)과 지속가 능성(sustainability)을 인정받았다. 지금은 과거 카흐리즈가 있던 지역의 지방정부 및 마을 주 민들 스스로 큰 관심을 가지고 사업을 위한 재원도 직접 부담하여 카흐리즈를 복원하고자 하고 있다.

\section{2) 카흐리즈 수자원시스템의 구조와 복원 방법}

이처럼 긍정적인 평가를 받고 있는 카흐리즈 수자원시스템의 구조는 매우 단순하다. 빗물 등 을 통해 지하로 스며든 지하수가 흐를 수 있는 지하수로와 수로가 지나가는 길에 간간이 통풍 및 지하수로의 유지관리를 위한 우물(Well)과 같은 구멍이 전부이다.

\section{〈 카흐리즈 기본 구조 〉}

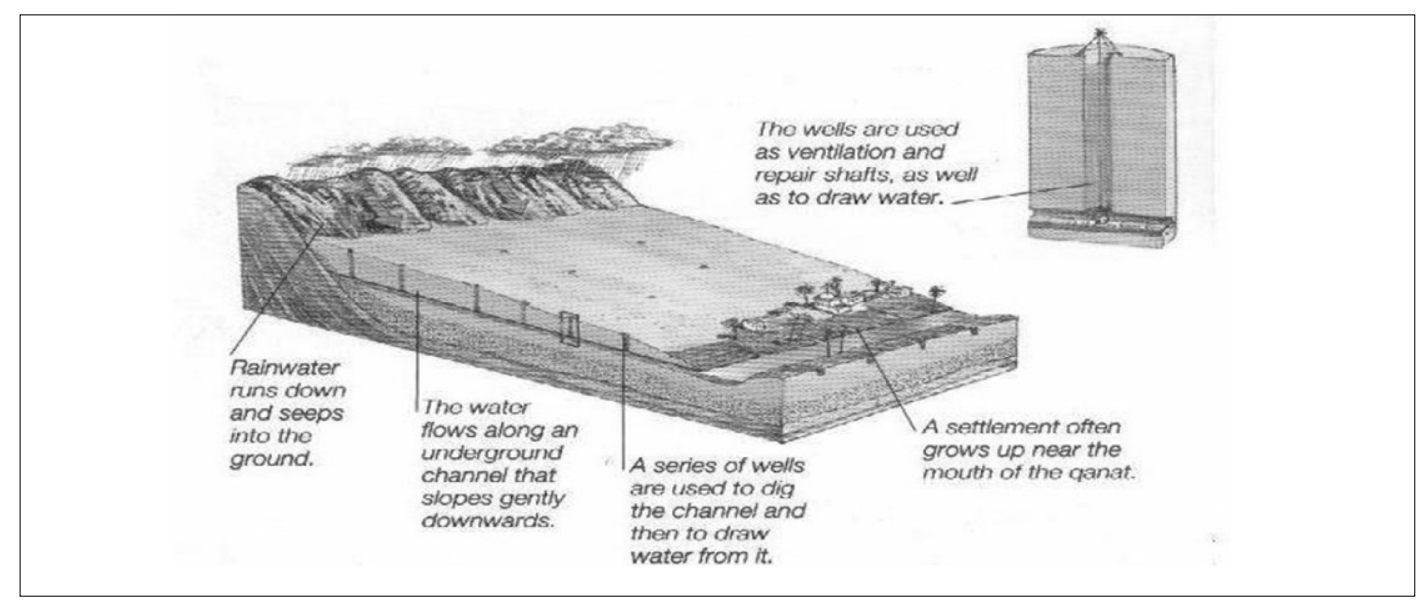

카흐리즈에서 well 이라고 불리는 시설은 (1)지하 카흐리즈 수로를 통해 물이 잘 흐를 수 있도 록 통풍 및 환기구의 역할을 하고, (2)향후 카흐리즈 시설에 문제 발생 시 이를 구간별로 점검 가 능케 하는 출입구 역할도 한다. 그러나 이 우물을 통해서 직접 물을 길어 올리지는 않는다. 물은 카흐리즈의 지하수로 끝으로 모이게 되고, 이렇게 물이 모이는 지점에 저수지 등을 조성하여 물 
을 저장하거나, 그 물을 주변 농지나 마을에서 쉽게 끌어다 사용할 수 있도록 별도 관로 등을 만 들기도 한다.

즉, 이러한 구조의 카흐리즈를 복원한다는 의미는 사람이 직접 지하수로와 우물의 막힌 부분 을 딿어(훍과 돌 등을 제거) 지하수가 원활히 흐를 수 있도록 하는 것이다. 훼손된 카흐리즈를 복원할 경우 당초 물이 흐르지 않거나 많아야 초당 $3-5 \mathrm{~L}$ 정도 흐르는 수준에서, 초당 50$100 \mathrm{~L}$ 가까이 물이 흐르게 되고, 이러한 물은 카흐리즈 복원 후 수질에 따라 농수 또는 식수로 구분하여 사용할 수 있다.

\section{〈 카흐리즈 복원 작업 〉}

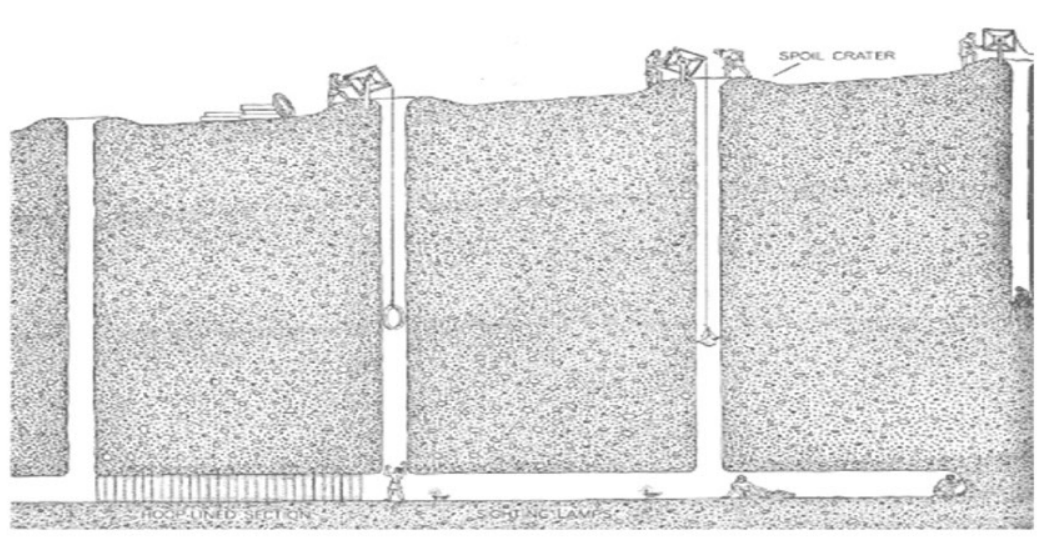

또한, 카흐리즈는 땅 속에 있기 때문에, 복원작업 시 중요한 기술적인 부분은 지상에서 보이 지 않는 훼손된 카흐리즈를 찾는 것과 물이 제대로 흐를 수 있는 지하수로의 방향을 예측하는 것이다. 물론, 처음으로 훼손된 카흐리즈를 찾을 때는 지역 주민들의 과거 카흐리즈 위치에 대 한 기억을 통해 대상지역에 접근하지만, 카흐리즈의 정확한 시작점과 끝점의 위치를 찾는 것은 카흐리즈 복원사업 전문가들의 노하우와 기술을 요구한다.

특히, 카흐리즈는 물이 지대간 경사차이로 흐르는 원리이기 때문에, 경사차이를 잘못 측정하 여 복원할 경우 물이 전혀 흐르지 않을 수 있다. 따라서, 지상에서 육안으로는 확인하기 어려운 지대간 경사차이를 정확히 측정하여, 복원될 지하수로의 방향을 정하는 것은 사업의 성공을 위 해 아주 중요한 요소이다. 또한, 카흐리즈 사업은 사람이 직접 지하로 내려가서 작업하기 때문 에, 우물의 깊이가 20-30m 되기도 하여 낙하사고와 지하수로 내에서 작업 시 지하수로가 무너 질 수도 있어 평소에도 큰 주의를 요구한다. 이에 숙련된 기술자(Kankans)를 고용하고 철저한 안전교육을 통해 사고를 방지하기 위한 노력이 필요하다. 


\section{3) 카흐리즈 복원사업의 주요내용 및 추진실적}

카흐리즈 복원사업은 위에서 주로 설명한 카흐리즈 시스템 자체를 복원하는 것 이외에, 카흐 리즈로부터 물 사용이 직접적으로 필요한 마을 또는 농지까지의 수로 건설, 공동 수자원시설인 카흐리즈를 분쟁 없이 사용하기 위한 물사용자그룹(Water Users Committees)의 조직(절반가 량을 여성으로 구성) 및 운영 교육, 카흐리즈 복원 및 유지관리 기술자(Kankans)를 양성하는 활동이 있다. 또한, 카흐리즈를 복원하는 비용도 약 $15 \%$ 가량을 지역주민이 부담하게 함으로써 사업에 대한 주인의식을 제고하고, 향후 유지관리에도 지속적인 관심을 가질 수 있도록 사업 내 용이 구성되어 있다.

이러한 사업내용을 기본으로 국제이주기구(IOM)는 1998년 나흐치반 지역의 사업을 시작으 로 지난 2011년말까지 약 13년 동안 150 개 가량의 카흐리즈 시스템을 복원하였다. 이를 통해 약 7,000 가구가 소유하고 있는 $5,000 \mathrm{ha}$ 의 경작지에 대한 농수공급과 약 10,000 가구에 대한 식수 공급이 가능하게 되었다. 또한, 카흐리즈를 유지보수 관리할 기술자인 Kankans도 300명 가량 양성하여 지역의 일자리 창출에도 기여하였다.

$\mathrm{IOM}$ 은 사업을 추진하면서 아제르바이잔 현지인력을 활용하여 직접 사업을 수행하였고, 주요 공여기관인 UNDP, CIDA, European Commision, US BUREAU OF PRM(POPULATION, REFUGEES \& MIGRATION), SDC(Swiss Agency for Development and Cooperation) 등이 동 사업의 재원을 지원하였다.

또한, 우리정부를 대표하여 KOICA도 2010년 7월부터 2012년 12월까지 약 30개월 동안 120 만불의 무상원조 자금으로 아제르바이잔 북서부 지역에 약 20 여개의 카흐리즈를 복원(수혜자 약 3,000 가구 규모)하고, 각 카흐리즈별로 물사용자그룹 조직 및 역량강화, Kankans을 양성 하는 내용으로 구성된 사업을 지원하고 있다.

\section{4) 카흐리즈 복원사업의 효과 및 평가}

카흐리즈 복원사업을 평가하기에 앞서, 이 사업이 중요한 이유는 무엇보다도 인간의 생활에 있어서 가장 기본적이고 필수적인 물과 관련된 문제를 해결한다는데에 있다. 물이 개발에서 가 지는 중요성은 물과 직접적인 관련이 있는 MDGs 7 번째 목표 내 지표인 '안전하고 깨끗한 식수 및 기본적인 위생처리시설에 접근 못하는 인구비율 반감 을 넘어, 주요한 개발과제에 영향을 미 치는 근본적인 원인으로서도 작용한다. 원활한 물공급 여부와 위생적인 하수처리 시설 유무는 
말라리아 발병율, 아동의 학교 출석율, 물부족으로 인한 여성의 하루일과 등에도 직접적인 영향 을 미치는 요소로서, 물 문제는 여러 개발과제 중에서도 가장 기본적으로 해결되어야 하는 부분 이다.

카흐리즈 수자원시스템 복원사업은 이렇듯 중요한 물 문제를 해결하기 위해 아제르바이잔 서 부지역 현지에 가장 적합한 방법으로 사업이 구성되어 추진되고 있으며, 크게 6가지면에서 사 업을 긍정적으로 평가할 수 있다.

우선, 경제적이다. 카흐리즈 1 개를 복원하고, 연결수로 건설 및 주민들의 역량강화를 위한 사 업비용은 카흐리즈에 따라 약 3-6만불 수준이며, 수혜자는 마을 크기에 따라 약 300-500명 수준에 달한다. 복원 후 카흐리즈 수자원 시스템을 유지 · 관리하는데 필요한 비용은 카흐리즈 를 점검하고 쌓인 흙과 돌 등을 일부 제거하는 인건비 외에 거의 들지 않는다. 우물을 파는 관정 사업과 비교하여 사업비용과 사후관리비용 면에서 훨씬 경제적으로 평가된다.

둘째로, 친환경적이다. 카흐리즈는 기본구조에서도 알 수 있듯이 중력으로 인해 물이 흐르고 공급됨으로써, 물을 공급하기 위한 부가적인 에너지가 필요하지 않다. 우물 시설 및 현대화된 상수도 공급시설과 달리 전기 등의 에너지가 전혀 필요하지 않다.

셋째로, 지속가능하다. 이는 경제적이고 친환경적인 특성과도 밀접한 관련이 있으나, 또 하나 중요한 부분은 현지 주민들이 배우기 어려운 특별한 기술 없이도, 현지주민들에 의해 카흐리즈 는 지속적으로 관리될 수 있다는 것이다. 이는 넓은 의미의 적정기술(Appropriate Technology $)^{4)}$ 의 개념과도 맞닿아 있다.

넷째로, 주민들의 거버넌스(Governance) 향상에도 기여한다. 카흐리즈 시스템은 24 시간 동 안 물이 계속해서 흐르기 때문에 마을 내 일부 저수지 등을 조성 - 저장하거나, 물사용자그룹을 통해 사용 시간대(24시간 기준)를 정하여 물을 사용해야 한다. 이에 따라, 마을 주민 간에 분쟁 없이 물을 사용하기 위해서는 물사용자그룹의 조직 및 운영이 중요하며, 이러한 과정(규칙준수 및 분쟁시 협의 등)을 통해 마을 내 거버넌스 발전에도 기여 가능하다.

다섯째로, 일자리를 창출한다. 카흐리즈를 복원, 유지, 관리하는 일은 기술적인 부분과 지하

4) 적정기술(Appropriate Technology)은 기술적 관점에서 지역적, 문화적, 경제적 조건과 양립가능하고, 지역적으 로 물질과 에너지원이 이용가능하며, 그리고 그 지역 사람들에 의해 그 도구와 과정들이 유지, 작동할 수 있을 때 적절한 것으로 여겨진다. 
에서 일을 해야 하는 위험성 때문에 마을의 모든 사람들이 할 수 있는 일은 아니다. 그러나, 마 을 주민 가운데 신체 건강한 사람의 경우 교육을 통해 누구든지 카흐리즈 관련 기술자가 될 수 있으며, 카흐리즈 복원사업 후에도 유지 관리가 필요하므로, 이를 위한 일을 지속적으로 할 수 있다.

마지막으로, 아제르바이잔 전통문화유산을 복원하는 일이다. 카흐리즈는 주민들에게 물을 공 급해주는 실질적인 기능이 가장 중요하지만, 카흐리즈 시스템이 아제르바이잔 특정지역의 전통 적인 시스템으로서 이를 복원하는 일은 자연스럽게 아제르바이잔의 전통문화유산을 복원하는 일이기도 하다.

이처럼, 카흐리즈 시스템은 다양한 면에서 장점을 지니고 있다. 다만, 카흐리즈 복원 시 지하 에서 작업을 해야 함에 따라 발생하는 위험과 카흐리즈 시스템을 일반화된 모델로 만들어 다른 지역에 적용할 수 없다는 점은 카흐리즈 복원사업의 한계일 수 있다. 그러나, 카흐리즈 시스템 이 가능한 아제르바이잔 서부 산간지역에서는 이보다 더 효율적이고 효과적인 시스템은 없는 것 으로 평가되면서, 지난 13 년간 다양한 공여기관들로부터 지원을 받으며 사업이 진행되어 왔다.

\section{4. 한국 ODA에 대한 시사점}

카흐리즈 수자원시스템 복원사업은 아제르바이잔 특정지역에서 추진된 하나의 작은 사업이지 만, 그 사업의 예를 통해 우리나라 ODA 사업에 주는 시사점을 간단히 3가지로 정리해보고자 한다.

첫째, $\mathrm{ODA}$ 사업은 수원국 여건에 적합하고 어려운 부분이 없어 현지인들이 지속적으로 관리 가능한 사업이 발굴되어 지원되어야 한다. 카흐리즈 수자원시스템의 구조는 단순하여 지속적인 유지관리에 많은 비용과 기술을 필요로 하지 않는다. 이는 현지인의 수준에서도 지속적으로 유 지 · 관리를 가능케 하는 적정기술의 의미와도 기본적으로 통하는 부분이다. 그러나, 이러한 부 분이 $\mathrm{ODA}$ 사업을 추진함에 있어서 가장 당연 시 되어야 할 부분처럼 보이나, 실제 $\mathrm{ODA}$ 사업 을 수행할 때 가장 고려하기 어려운 부분일 수도 있다. 특히, 공여국측에서 의도하지 않더라도, 수원국의 상황을 잘 이해하지 못하거나 또는 공여국이 해 줄 수 있는 범위가 국한되어 있을 경 우, 오히려 수원국 현지 특성에 적합한 사업을 발굴하는 것은 쉬운 일이 아니다. 예를 들어, 우 리의 관점에서 특정지역에 물을 공급하는 방법은 현대화된 상하수도 시설을 건설하거나 우물을 파는 정도일 뿐이지만, 카흐리즈 복원사업과 같이 수원국의 환경과 특성을 제대로 이해한 후 사 
업을 발굴할 경우 완전히 다른 방식으로 사업을 추진할 수 있다. 이는 일반적으로 통용되는 방 법 또는 기술(현대화된 상하수도시설 건설 등) 일지라도, 특정지역의 환경에서는 경제성이나 지 속가능성 등 여러 가지 면을 고려했을 때 그보다 더 나은 다른 방법이 있다는 것을 보여준다. 이 처럼, 앞으로 한국 $\mathrm{ODA}$ 사업의 효과와 질을 제고하기 위해서는 우리의 경험을 통해 우리가 줄 수 있는 것이 무엇인지를 먼저 찾기보다, 수원국의 문제를 해결하기 위한 방법을 현장에서 찾으 려고 하는 자세가 중요하다.

둘째, 한국의 ODA 규모가 커질수록 국내 또는 국제적으로 비교우위에 근거한 지속적이고 유 연한 파트너십이 필요하다. 카흐리즈 복원사업이 지난 13년 동안 성공적으로 추진될 수 있었던 이유는 카흐리즈 사업의 효과성을 인정한 공여기관들이 파트너십을 가지고 끊임없이 재원을 투 자하였다는 데에 있다. IOM이 지역의 주민들을 직접 동원하고 카흐리즈 복원사업을 실제로 수 행하는 역할을 하였다면, $\mathrm{KOICA}$ 를 포함한 여러 공여기관들(UNDP, CIDA, EC, US BUREAU OF PRM, SDC)은 그 사업이 진행될 수 있도록 자금을 지원하였다. 둘 중 어느 하나 라도 그 역할이 부족했더라면 사업은 추진될 수 없었을 것이다. 이처럼, 모든 ODA 사업을 우리 가 직접 수행하려는 부담을 가질 필요는 없다. 사업의 효과성을 극대화시킬 수 있는 또 다른 주 체가 있다면 그 주체(국제기구, 양자기관, $\mathrm{NGO}$, 대학교, 민간기업 등)와의 파트너십을 통해 사 업을 추진할 수 있다. 만약 KOICA도 특정 분야에서 비교우위를 가질 수 있는 부분이 있다면 앞 으로 다른 기관으로부터 재원을 지원받아 사업을 수행할 수도 있으며, 궁극적으로 ODA 사업의 효과성 제고를 위해 이러한 자금지원 방식 이외에도 다양한 형태의 파트너십에 대해 고민할 필 요가 있다.

마지막으로, $\mathrm{ODA}$ 사업의 효과성 제고를 위해서는 장기간의 사업추진을 통해 경험을 축적하 고 노하우를 쌓는 것이 중요하다. 지난 13 년간 IOM은 약 150 개 이상의 카흐리즈를 복원하면 서, 복원 작업 시 발생할 수 있는 위험에 철저히 대비하여 아직까지 단 1 명의 인명사고도 발생시 키지 않았다. 또한, 복원 후 마을주민 모두가 물을 제대로 사용하기 위해서는 물사용자그룹의 구성과 역량강화 교육이 가장 중요한 부분인데, IOM은 이에 대한 노하우를 가지고 교육을 실시 하여 마을주민들이 복원된 카흐리즈의 물을 분쟁없이 사용하게 하였다. 장기간 사업을 추진하 는 것에 대한 가치는 카흐리즈 사업뿐만 아니라, 남수단에서 의료봉사 활동을 하시다 돌아가신 故이태석 신부의 경우를 보더라도, 그 당시 도움을 받았던 마을사람들의 마음속에 아직까지 깊 이 남아 있을 정도로 그 효과는 대단하다. 이처럼, 한국의 $\mathrm{ODA}$ 사업도 이제는 장기적인 관점에 서 사업을 기획하고 추진하여, 일회성(이벤트성) 원조에서 벗어나 궁극적으로 수원국의 발전에 기여하는 사업으로 변화되어야 할 것이다. 


\section{참고문헌}

\section{1. 국내문헌}

홍성욱 외, 2010 , 적정기술을 활용한 ODA의 효과적 추진방안에 대한 연구, 특허청 용역보고서

\section{2. 국외문헌}

아제르바이잔 정부, 2008-2015년 빈곤감소와 지속가능한 발전을 위한 국가 계획(SPPRSD : State Program on Poverty Reduction and Sustainable Development)

아제르바이잔 정부, 2009-2013년 지역별 사회경제개발전략(SPSEDR : State Programme on Socio-Economic Development of the Regions)

IOM, 2009, Kahriz Rehabilitaion Project Proposal

SDC, 2007, Impact Assessment of the Community-Owned Sustainable Water Use and Agricultural Initiatives Project

SDC, 2007, Report of the External Review, Community-Owned Sustainable Water Use and Agricultural Initiatives' Project Azerbaijan Phase II 